\title{
Can Yogic Breathing Techniques Like Simha Kriya and Isha Kriya Regulate COVID-19-Related Stress?
}

\author{
Manjari Rain ${ }^{1}$, Balachundhar Subramaniam ${ }^{2}$, Pramod Avti ${ }^{*}$, Pranay Mahajan ${ }^{4}$ and \\ Akshay Anand ${ }^{1,5,6 *}$ \\ ${ }^{1}$ Department of Neurology, Post Graduate Institute of Medical Education and Research, Chandigarh, India, ${ }^{2}$ Center for \\ Anesthesia Research Excellence, Beth Israel Deaconess Medical Center, Harvard Medical School, Boston, MA, United \\ States, ${ }^{3}$ Department of Biophysics, Post Graduate Institute of Medical Education and Research, Chandigarh, India, \\ ${ }^{4}$ Department of Hospital Administration, Post Graduate Institute of Medical Education and Research, Chandigarh, India, \\ ${ }^{5}$ Centre for Mind Body Medicine, Post Graduate Institute of Medical Education and Research, Chandigarh, India, ${ }^{6}$ Centre of \\ Phenomenology and Cognitive Sciences, Panjab University, Chandigarh, India
}

The global impact of Coronavirus Disease 2019 (COVID-19) is tremendous on human life, not only affecting the physical and mental health of population but also impacting the economic system of countries and individual itself. The present situation demands prompt response toward COVID-19 by equipping the humans with strategies to overcome the infection and stress associated with it. These strategies must not only be limited to preventive and therapeutic measures, but also aim at improving immunity and mental health. This can be achieved by yogic breathing techniques. In this perspective, we emphasize the importance of yogic breathing, Simha Kriya and Isha kriya, the simple yet effective breathing techniques.

Keywords: COVID-19, Isha Kriya, novel coronavirus, Simha Kriya, yogic breathing, breathing techniques

\section{INTRODUCTION}

Traditional yogic systems that involve breathing exercises (Pranayama), yoga postures (Asanas), chants and meditation have been known to reduce physical and mental stress, enhance lung functions, and immunity (Hakked et al., 2017). Mindful meditation for a single day is able to decrease the gene expression of histone deacetylase genes (HDAC 2, 3, and 9) and pro-inflammatory genes (RIPK2 and COX2) in experienced meditators (Kaliman et al., 2014). Interestingly, Yoga practice has shown to decrease the oxidative stress markers and up-regulate the expression of telomerase genes, such as telomerase reverse transcriptase and telomerase RNA, suggesting increased cellular viability and reduced cellular aging (Duraimani et al., 2015). Studies have shown that Yoga therapy/meditation can improve health and well-being of a diseased individual by reducing stress besides boosting the immune response (Thirthalli et al., 2013; Danhauer et al., 2019; Tang et al., 2020; Venkatesh et al., 2020). Mindfulness-based cognitive therapy can significantly reduce stress, depression and anger, when administered in-person, or virtually (Schanche et al., 2020; Kuo et al., 2021; Orosa-Duarte et al., 2021; Strauss et al., 2021). Similar to Yoga, mindfulness-based

Abbreviations: ACE2, Angiotensin-converting enzyme 2; ARDS, Acute respiratory distress syndrome; CD4, Cluster of differentiation 4; CD8, Cluster of differentiation 8; COVID-19, Coronavirus Disease 2019; COX2, Cyclooxygenase 2; HCWs, Health care workers; HDAC2, Histone Deacetylase 2; HDAC3, Histone Deacetylase 3; HDAC9, Histone Deacetylase 9; LDBT, Isha kriya or long duration breathing technique; MCP-1, Monocyte chemoattractant protein-1; RIPK2, Receptor-interacting serine/threonine-protein kinase 2; SARS, Severe Acute Respiratory Syndrome; SARS-CoV-2, Severe acute respiratory syndrome coronavirus 2/novel coronavirus; SDBT, Simha kriya or short duration breathing technique. 
techniques also have immune modulatory effects (Reich et al., 2017; Andrés-Rodríguez et al., 2019).

Some studies suggest the role of yogic controlled breathing in reducing the stress levels, controlling mood fluctuations such as anxiety and depression, and at the same time improving quality of life by motor co-ordination, cognitive performance, heart rate variability, and more (Bernardi et al., 2000; Sharma et al., 2014; Gonçalves et al., 2016; Erdoğan Yüce and Taşc1, 2020). Systolic and diastolic blood pressure is improved immediately after practicing Pranayama (Pramanik et al., 2009; Bhavanani et al., 2011). It is notable that practicing Yoga, especially breathing techniques, may be beneficial to control anxiety, stress and to some extent modulate immune response. However, validating such technique in a clinical set up is obligatory.

Enhanced anxiety and stress levels were reported worldwide in Coronavirus Disease 2019 (COVID-19) pandemic amongst health care workers (HCWs), quarantined individuals (suspected cases), convalescent individuals and COVID-19 positive cases due to sudden rise in cases and inability to manage COVID-19 with medication available in the early stages of pandemic (Luo et al., 2020; Ornell et al., 2020; Pfefferbaum and North, 2020; Halperin et al., 2021). Psychological stress has been reported to increase during the lockdowns, quarantine periods and after stayat-home orders (Ozamiz-Etxebarria et al., 2020). Anxiety and stress have also increased among people due to recent vaccination drive; some are anxious while waiting for their first or second vaccine shot while others have doubts on efficacy of vaccines, which are still under trial. Psychological stress is a known factor which is detrimental to immune modulation and stress can diminish the immune response post vaccination (Glaser et al., 1998; Segerstrom and Miller, 2004; Pedersen et al., 2009; Madison et al., 2021). It is widely believed that stress associated with COVID-19 may worsen the severity of infection and may render otherwise healthy individuals susceptible to COVID-19 (Cohen, 2021).

Novel coronavirus disease of 2019, often referred as COVID-19 was declared pandemic in March, 2020 (Cucinotta and Vanelli, 2020). Since the virus was reported, there are $119,220,681$ confirmed cases of COVID-19, including 2,642,826 deaths worldwide as of 5:13 pm CET, 14 March 2021 (WHO, 2020b). COVID-19 is caused by SARS-CoV-2 (novel coronavirus), which has $82 \%$ genome similarity with Severe Acute Respiratory Syndrome (SARS) causing virus, SARS-CoV (Chan et al., 2020). SARS-CoV-2 spreads rapidly than SARS-CoV and replicates actively in upper respiratory tract (Hou et al., 2020; Sungnak et al., 2020; Wölfel et al., 2020; Ziegler et al., 2020).

Pneumocytes in lungs are invaded by SARS-CoV-2 leading to collapse of the air sacs (Zhao et al., 2010). An immune response is induced as macrophages and neutrophils rush to the site, initiating inflammation that lead to pneumonia (Wang et al., 2020; Zeng et al., 2020). Death in severe cases occurs because of pneumonia and acute respiratory distress syndrome, where deposition in alveoli and small blood vessels around alveoli is formed impairing the gaseous exchange (Welty-Wolf et al., 2002; Levi et al., 2003; Moore et al., 2020; Tian et al., 2020). Hence, managing the immune response could be one of the treatment strategies for COVID-19.
Although with low mortality rates, there is accelerating rise in number of deaths because of rapid transmission and various mutated strains of SARS-CoV-2 (Fang et al., 2021; Leung et al., 2021; Ozono et al., 2021), resulting in stress among people. The treatments that are or were practiced for COVID-19 include Hydroxychloroquine, Remdesivir, Lopinavir-Ritonavir combination with or without interferon, Dexamethasone and convalescent plasma therapy (Antinori et al., 2020; Grein et al., 2020; Hung et al., 2020; Okour et al., 2020; Valk et al., 2020). Remdesivir is the only United States Food and Drug Administration (FDA) approved drug, which can be used in combination with Baricitinib for faster recovery (Kalil et al., 2020).

COVID-19 is a public health emergency; hence, FDA has issued Emergency Use Authorization (EUA) to a few vaccines, which are under trial. In December 2020, two vaccines, i.e., Pfizer-BioNTech COVID-19 Vaccine and Moderna COVID-19 Vaccine were granted EUA from FDA. Pfizer-BioNTech COVID19 Vaccine was the first to receive EUA from WHO followed by Astra Zeneca/Oxford COVID-19 vaccine, manufactured by the Serum Institute of India and SKBio (WHO, 2020a). Two prominent vaccines namely, Astra Zeneca/Oxford COVID-19 under the local name of Covishield and Covaxin, developed by Bharat Biotech, India are being administered in India.

Precautionary measures such as $\mathrm{N}-95$ or regular masks, hand-washing, use of sanitizers and social distancing can be effectively supplemented with vaccination and immune enhancing measures such as a good diet, physical exercises, yogic breathing exercises, and meditative techniques including mindfulness. We hypothesize that Yoga, especially the breathing technique, maybe instrumental in COVID-19 management as an adjunct approach. In this article we have discussed the psychological and physiological improvements achieved by practicing Yoga, including Pranayama, or meditation or both and tried to emphasize its role in COVID-19 management.

\section{YOGA AND BREATHING TECHNIQUES IN REDUCING THE DISEASE BURDEN}

\section{Yogic Breathing Techniques and Their Effects on Human Systems}

Yoga originated in ancient India and includes physical, mental, and spiritual practices with an explicit emphasis on different breathing patterns. Yogic breathing in a controlled manner known as Pranayama is one of the eight limbs of traditional yoga. Furthermore, Pranayamas themselves are of eight types, (1) Surya Bhedana or Sun-piercing Breath or Right Nostril Breathing, (2) Ujjayi or Victorious or Ocean Breath, (3) Sheetkari or Hissing Breath, (4) Sheetali or Cooling Breath, (5) Bhastrika or Bellows Breath, (6) Bhramari or Humming Bee Breath, (7) Moorchha or Swooning Breath, and (8) Plavini or Floating Breath (Muktibodhananda, 2012). According to "Hatha Yoga Pradipika", these Pranayamas have various benefits on the mind and body as a whole (Muktibodhananda, 2012). 
Surya Bhedana Pranayama increases heat in body; it helps body vitality, treat anxiety, depression and lack of energy. Ujjayi Pranayama is good for throat, cardio-respiratory, nervous and digestive systems. Sheetkari Pranayama calms mind and reduces negative emotions, improves immunity, memory, purifies blood and refreshes the body (Thanalakshmi et al., 2014). Sheetali Pranayama can be beneficial in summers as it cools down the mind and body. It also reduces bad breath, regulates blood pressure and elevates mood. Sheetkari and Sheetali Pranayamas reduce blood pressure in hypertensives (Shetty, 2017). Bhastrika Pranayama energizes mind and body by maximizing lung capacity. It helps in respiratory problems such as sinus, bronchitis and it also improves awareness and perceptive power of senses (Budhi et al., 2019). Bhramari Pranayama relieves tension, anger and anxiety, reduces blood pressure, diminishes headache and migraines, and improves concentration and memory (Kuppusamy et al., 2018). Moorchha Pranayama promotes happiness of mind, helps the mind to draw inward, removes body fat and reduces muscle weakness. Plavini is an advanced Pranayama, which increases the body capacity to sustain without food and water for several days; helps to detoxify the body and decreases stress.

\section{Yogic Breathing on Stress Levels and Immunity}

Emerging studies suggest the positive role of Pranayama in the regulation of hypothalamic-pituitary-adrenal axis and inflammatory processes (Kiecolt-Glaser et al., 2010; Kaliman et al., 2014; Bower and Irwin, 2016). They may serve as adjunct to modern approaches if not as a new avenue for the non-pharmacological treatment regime. Regular Yoga practice improves mental health, by increasing mental calmness, reducing stress, improving physical health, breathing and sleep (Cartwright et al., 2020; Haller et al., 2020; La Torre et al., 2020; Sahni et al., 2021). Meditation and mindfulness also improve psychological well-being and reduce stress and anxiety (Kwok et al., 2019; Hilcove et al., 2020; Ofei-Dodoo et al., 2020; Sadhasivam et al., 2020). These benefits are documented in the ancient Indian texts; however, the need to establish these benefits by using modern tools has triggered many scientific studies on Yoga, meditation and breathing exercises. Table 1 shows recent trial studies, which have shown reduction in stress, anxiety or depression in different study set up.

Yoga has been shown to improve quality of life, reduce fatigue and sleep disturbances in breast cancer patients (Cramer et al., 2017). Yoga protocol designed in India, specifically to manage diabetes can reduce co-morbidity of dyslipidemia in diabetic patients (Nagarathna et al., 2019b). Further, Yoga practice was also able to limit stress-related inflammation in women (KiecoltGlaser et al., 2010). Yoga intervention, including Pranayama and Asana, increases CD4, a marker of helper T cells, in HIV patients indicating improved immunity, which is prominently hampered in HIV (Joseph et al., 2015). Similarly, immunity improved in HIV-positive children/adolescents after Yoga intervention, indicated by elevation in CD4 and shifting of CD4/CD8 ratio in the normal range (Chandra et al., 2019). The pro-inflammatory cytokines IL-1 $\beta$, IL-8, and monocyte chemotactic protein-1 (MCP-1) levels were reportedly reduced in the Yoga intervention (Pranava Pranayama) group (Twal et al., 2016). It is known that IL- $1 \beta$ induces the brain cyclooxygenase- 2 levels, which in turn has a vital role in the stress and pain management (Gurung and Kanneganti, 2015). However, it is also important to consider the role of IL-1 $\beta$ as an anti-inflammatory target for chronic obstructive pulmonary disease (COPD; Dhimolea, 2010). On the other hand, IL-8, a neutrophil chemoattractant, is known to be elevated in the chronic pulmonary disorder patients including COPD, cystic fibrosis, acute respiratory disorder syndrome and asthma (Aggarwal et al., 2000; McGarvey et al., 2002). MCP-1 is known for its role in activation by macrophages, monocytes, lymphocytes, and airway epithelial cells (Lundien et al., 2002). Enhanced levels of MCP-1 have chemotactic activity on monocytes, enhance the T cells activity (Carr et al., 1994), and stimulate transforming growth factor- $\beta$ and collagen synthesis (Gharaee-Kermani et al., 1996; Hogaboam et al., 1999). In rheumatoid arthritis, Yoga affects the psycho-neuro-immune axis by reduction in inflammatory cytokines and improvement in mind-body communicative markers and quality of life; disease activity was also reduced in yoga group (Gautam et al., 2020).

Breathing techniques and meditation have shown to decrease inflammation in Axial Spondyloarthritis (Buijze et al., 2019). Breathing techniques, especially the expiratory techniques improve lung functions, and immune response in bronchial asthma patients (Asimakos et al., 2018). Bhastrika Pranayama, the most popular Pranayama, improves lung function in healthy individuals (Kuppusamy et al., 2018). Shambhavi Mahamudra kriya, a 21-min Isha yoga meditation from the Isha foundation, India, include deep breathing and meditation reducing stress as was measured by Perceived Stress Scale (Peterson et al., 2017). Other breathing techniques that improve the pulmonary rehabilitation in cases of COPD include the diaphragmatic and pursed-lip breathing (Martarelli et al., 2011; Valenza et al., 2014). Both the techniques results in inspirational capacity, slow breathing rate, longer exhalation time, improved oxygen saturation, lung emptying, and dynamic hyperinflation reduction in the COPD cases (Casaburi et al., 1997; Kaminsky et al., 2017).

Studies have shown improved ventilatory function in individuals performing yoga or breathing exercise. Improved ventilatory function was reported from lowered respiratory rate and increase in tidal volume, forced vital capacity, increase in forced expiratory volume at the end of 1st second, maximum voluntary ventilation, peak expiratory flow rate and breath holding time (Vieira et al., 2014; Joo et al., 2015; Alaparthi et al., 2016; Csepregi et al., 2019). Learning to adopt new breathing techniques that help to improve lung capacity, volume and function may play a role in enhancing disease recovery, such as flu, common cold and COVID-19.

\section{ISHA KRIYA: A SIMPLE BREATHING TECHNIQUE}

Yoga uses the traditional wisdom of using breathing for self regulation. Isha Foundation, established by Sadhguru, a yogi, has 
TABLE 1 | Stress and Anxiety reduction by Yoga and mindfulness.

\begin{tabular}{|c|c|c|c|c|c|c|}
\hline $\begin{array}{l}\text { Clinical trial } \\
\text { studies }\end{array}$ & Pubmed ID & Sample size & Age, years & $\begin{array}{l}\text { Disorder or } \\
\text { disease } \\
\text { targeted or } \\
\text { study group } \\
\text { type }\end{array}$ & Technique & $\begin{array}{l}\text { Effect on } \\
\text { psychological } \\
\text { stress, } \\
\text { anxiety, or } \\
\text { depression }\end{array}$ \\
\hline $\begin{array}{l}\text { Divya et al., } 2021 . \\
\text { Global Advances in } \\
\text { Health and } \\
\text { Medicine }\end{array}$ & 33623726 & 92 & $43.1 \pm 11.1$ & $\begin{array}{l}\text { Health care } \\
\text { workers }\end{array}$ & $\begin{array}{l}\text { Sudarshan } \\
\text { Kriya Yoga, } \\
\text { workshop of } \\
4 \text { days followed } \\
\text { by } 40 \text { days of } \\
\text { self-practice }\end{array}$ & $\begin{array}{l}\text { Stress, Anxiety } \\
\text { and depression } \\
\text { were reduced. }\end{array}$ \\
\hline $\begin{array}{l}\text { Sadhasivam et al., } \\
2020 . \\
\text { Evidence-Based } \\
\text { Complementary } \\
\text { and Alternative } \\
\text { Medicine }\end{array}$ & 32595741 & 348 & - & $\begin{array}{l}\text { Healthy } \\
\text { participants }\end{array}$ & $\begin{array}{l}\text { Bhava } \\
\text { Spandana } \\
\text { Program (Yoga } \\
\text { and meditation } \\
\text { retreat) for } \\
4 \text { days }\end{array}$ & $\begin{array}{l}\text { Anxiety and } \\
\text { depression } \\
\text { were reduced. } \\
\text { Quality of life } \\
\text { improved }\end{array}$ \\
\hline $\begin{array}{l}\text { Haller et al., } 2020 . \\
\text { Current } \\
\text { Pharmaceutical } \\
\text { Design }\end{array}$ & 33308110 & 57 & $51.3 \pm 10.5$ & Breast cancer & $\begin{array}{l}\text { Yoga and } \\
\text { mindfulness } \\
\text { technique for } \\
66 \mathrm{~h}\end{array}$ & $\begin{array}{l}\text { Stress, Anxiety } \\
\text { and depression } \\
\text { were reduced. }\end{array}$ \\
\hline $\begin{array}{l}\text { Marshall et al., } \\
\text { 2020. International } \\
\text { Journal of } \\
\text { Environmental } \\
\text { Research and } \\
\text { Public Health }\end{array}$ & 32825677 & 13 & $20.8 \pm 0.8$ & $\begin{array}{l}\text { Physically } \\
\text { active and } \\
\text { healthy }\end{array}$ & $\begin{array}{l}\text { Meditative } \\
\text { (Hatha style) } \\
\text { yoga for } 30 \mathrm{~min}\end{array}$ & $\begin{array}{l}\text { Stress was } \\
\text { reduced }\end{array}$ \\
\hline $\begin{array}{l}\text { Pattnaik et al., } \\
\text { 2020. Journal of } \\
\text { Family Medicine } \\
\text { and Primary Care }\end{array}$ & 33110832 & 200 & - & $\begin{array}{l}\text { Oral cancer } \\
\text { patients }\end{array}$ & $\begin{array}{l}\text { Yoga for } \\
1 \text { month }\end{array}$ & $\begin{array}{l}\text { Stress was } \\
\text { reduced }\end{array}$ \\
\hline $\begin{array}{l}\text { McDonnell et al., } \\
\text { 2020. Integrative } \\
\text { Cancer Therapies }\end{array}$ & 33118443 & 49 & $\begin{array}{l}\text { Survivor }= \\
66.5 \pm 5.5 \\
\text { Family } \\
\text { member }= \\
60.2 \pm 14.1\end{array}$ & $\begin{array}{l}\text { Survivors of } \\
\text { non-small-cell } \\
\text { lung cancer }\end{array}$ & $\begin{array}{l}\text { Mindfulness- } \\
\text { based } \\
\text { intervention, } \\
\text { Breathe Easier } \\
\text { for } 2 \text { months }\end{array}$ & $\begin{array}{l}\text { Stress, Anxiety } \\
\text { and depression } \\
\text { were reduced. }\end{array}$ \\
\hline $\begin{array}{l}\text { Grahn Kronhed } \\
\text { et al., 2020. Journal } \\
\text { of Alternative and } \\
\text { Complementary } \\
\text { Medicine }\end{array}$ & 32543212 & 15 & $\begin{array}{l}71.8 \text { (median } \\
72, \text { range } \\
63-82)\end{array}$ & $\begin{array}{l}\text { Osteoporotic } \\
\text { Vertebral } \\
\text { Fracture }\end{array}$ & $\begin{array}{l}\text { Yoga and } \\
\text { mindfulness } \\
\text { technique, } \\
\text { once a week } \\
\text { for } 10 \text { weeks }\end{array}$ & $\begin{array}{l}\text { Stress was } \\
\text { reduced }\end{array}$ \\
\hline $\begin{array}{l}\text { Nirwan et al., } 2020 . \\
\text { Journal of } \\
\text { Complementary } \\
\text { and Integrative } \\
\text { Medicine }\end{array}$ & 32554833 & - & - & $\begin{array}{l}\text { Winter } \\
\text { expedition } \\
\text { members of } \\
\text { Indian Scientific } \\
\text { Antarctic } \\
\text { Expedition }\end{array}$ & $\begin{array}{l}\text { Yoga for } \\
10 \text { months }\end{array}$ & $\begin{array}{l}\text { Improvement in } \\
\text { stress-related } \\
\text { blood markers }\end{array}$ \\
\hline $\begin{array}{l}\text { Sharma et al., } \\
\text { 2020. Journal of } \\
\text { Alternative and } \\
\text { Complementary } \\
\text { Medicine }\end{array}$ & 32608989 & $\begin{array}{l}\text { Yoga, } n=33 \\
\text { Control, } n=33\end{array}$ & $\begin{array}{l}\text { Yoga }= \\
53.2 \pm 11.6 \\
\text { Control }= \\
51.5 \pm 8.2\end{array}$ & $\begin{array}{l}\text { Cardiovascular } \\
\text { diseases }\end{array}$ & $\begin{array}{l}\text { Asana, } \\
\text { Pranayama and } \\
\text { relaxation } \\
\text { technique, } \\
3 \text { days per } \\
\text { week for } \\
12 \text { weeks }\end{array}$ & $\begin{array}{l}\text { Anxiety and } \\
\text { depression } \\
\text { were reduced. } \\
\text { Quality of life } \\
\text { improved }\end{array}$ \\
\hline $\begin{array}{l}\text { Goldstein et al., } \\
\text { 2020. Journal of } \\
\text { American College } \\
\text { Health }\end{array}$ & 32667254 & 37 & $20.7 \pm 3.2$ & $\begin{array}{l}\text { Undergraduate } \\
\text { and graduate } \\
\text { students }\end{array}$ & $\begin{array}{l}\text { Sudarshan } \\
\text { Kriya Yoga for } \\
4 \text { days }\end{array}$ & $\begin{array}{l}\text { Stress was } \\
\text { reduced }\end{array}$ \\
\hline
\end{tabular}

(Continued) 
TABLE 1 | Continued

\begin{tabular}{|c|c|c|c|c|c|c|}
\hline $\begin{array}{l}\text { Clinical trial } \\
\text { studies }\end{array}$ & Pubmed ID & Sample size & Age, years & $\begin{array}{l}\text { Disorder or } \\
\text { disease } \\
\text { targeted or } \\
\text { study group } \\
\text { type }\end{array}$ & Technique & $\begin{array}{l}\text { Effect on } \\
\text { psychological } \\
\text { stress, } \\
\text { anxiety, or } \\
\text { depression }\end{array}$ \\
\hline $\begin{array}{l}\text { La Torre et al., } \\
\text { 2020. Journal of } \\
\text { Clinical Medicine }\end{array}$ & 32272758 & 40 & $47.3 \pm 10.9$ & $\begin{array}{l}\text { Health care } \\
\text { workers }\end{array}$ & $\begin{array}{l}\text { Yoga and } \\
\text { mindfulness } \\
\text { technique for } \\
4 \text { weeks }\end{array}$ & $\begin{array}{l}\text { Stress and } \\
\text { Anxiety were } \\
\text { reduced }\end{array}$ \\
\hline $\begin{array}{l}\text { Verma et al., } 2020 . \\
\text { Journal of } \\
\text { Education and } \\
\text { Health Promotion }\end{array}$ & 32318598 & 33 & $52.4 \pm 5.8$ & $\begin{array}{l}\text { Healthy } \\
\text { participants } \\
\text { (principal) }\end{array}$ & $\begin{array}{l}\text { Yoga for } \\
105 \text { min, twicw } \\
\text { a day for } \\
1 \text { week }\end{array}$ & $\begin{array}{l}\text { Stress was } \\
\text { reduced }\end{array}$ \\
\hline $\begin{array}{l}\text { Ofei-Dodoo et al., } \\
\text { 2020. Journal of } \\
\text { Occupational and } \\
\text { Environmental } \\
\text { Medicine }\end{array}$ & 32358474 & 43 & - & $\begin{array}{l}\text { Health care } \\
\text { workers }\end{array}$ & $\begin{array}{l}\text { Mindfulness- } \\
\text { based yoga for } \\
8 \text { weeks }\end{array}$ & $\begin{array}{l}\text { Stress and } \\
\text { Anxiety were } \\
\text { reduced }\end{array}$ \\
\hline $\begin{array}{l}\text { Cartwright et al., } \\
2020 . \\
\text { Complementary } \\
\text { Therapies in } \\
\text { Medicine }\end{array}$ & 32444036 & 10 & $53.6 \pm 13.2$ & $\begin{array}{l}\text { Rheumatoid } \\
\text { arthritis }\end{array}$ & $\begin{array}{l}\text { Yoga for } \\
16 \text { weeks }\end{array}$ & $\begin{array}{l}\text { Anxiety and } \\
\text { depression } \\
\text { were reduced. } \\
\text { Quality of life } \\
\text { improved }\end{array}$ \\
\hline $\begin{array}{l}\text { Hilcove et al., } 2020 . \\
\text { Journal of Holistic } \\
\text { Nursing }\end{array}$ & 32460584 & $\begin{array}{l}\text { Yoga, } n=41 \\
\text { Control, } n=39\end{array}$ & $\begin{array}{l}\text { Yoga }=42.4 \\
(24 \text { to } 69) \\
\text { Control }=42.5 \\
(24 \text { to } 64)\end{array}$ & $\begin{array}{l}\text { Health care } \\
\text { workers }\end{array}$ & $\begin{array}{l}\text { Mindfulness- } \\
\text { based yoga for } \\
6 \text { weeks }\end{array}$ & $\begin{array}{l}\text { Stress was } \\
\text { reduced }\end{array}$ \\
\hline $\begin{array}{l}\text { Tong et al., } 2020 . \\
\text { Journal of American } \\
\text { college health }\end{array}$ & 31944898 & $\begin{array}{l}\text { Study1, } \\
n=191 \\
\text { Study2, } \\
n=143\end{array}$ & $\begin{array}{l}\text { Study } 1 \\
20.0 \pm 1.4 \\
\text { Study2, } \\
19.8 \pm 1.4\end{array}$ & $\begin{array}{l}\text { Healthy } \\
\text { undergraduates }\end{array}$ & $\begin{array}{l}\text { Yoga A } 60 \text { min } \\
\text { session in } \\
\text { Study } 1 \text { and } \\
12 \text { weeks } \\
\text { intervention in } \\
\text { Study } 2\end{array}$ & $\begin{array}{l}\text { Stress was } \\
\text { reduced }\end{array}$ \\
\hline $\begin{array}{l}\text { Bressington et al., } \\
\text { 2019. Journal of } \\
\text { Affective Disorders }\end{array}$ & 30711868 & $\begin{array}{l}\text { Yoga, } n=23 \\
\text { Control, } n=27\end{array}$ & $\begin{array}{l}\text { Yoga }= \\
46.3 \pm 12.8 \\
\text { Control }= \\
49.3 \pm 9.1\end{array}$ & Depression & $\begin{array}{l}\text { Laughter Yoga, } \\
8 \text { sessions over } \\
4 \text { weeks }\end{array}$ & $\begin{array}{l}\text { Depression } \\
\text { was reduced }\end{array}$ \\
\hline $\begin{array}{l}\text { Kwok et al., } 2019 . \\
\text { JAMA Neurology }\end{array}$ & 30958514 & $\begin{array}{l}\text { Yoga, } n=71 \\
\text { Control, } n=67\end{array}$ & $\begin{array}{l}\text { Yoga }= \\
63.7 \pm 8.2 \\
\text { Control }= \\
63.5 \pm 9.3\end{array}$ & $\begin{array}{l}\text { Idiopathic } \\
\text { Parkinson } \\
\text { disease }\end{array}$ & $\begin{array}{l}\text { Mindfulness- } \\
\text { based yoga, } \\
90 \text { min for } \\
8 \text { weeks }\end{array}$ & $\begin{array}{l}\text { Anxiety and } \\
\text { depression } \\
\text { were reduced }\end{array}$ \\
\hline $\begin{array}{l}\text { Miyoshi, } 2019 . \\
\text { Journal of } \\
\text { Occupational } \\
\text { Health }\end{array}$ & 31368154 & 20 & 20 to 30 & $\begin{array}{l}\text { Health care } \\
\text { workers }\end{array}$ & $\begin{array}{l}\text { Yoga for } \\
4 \text { weeks }\end{array}$ & $\begin{array}{l}\text { Stress was } \\
\text { reduced }\end{array}$ \\
\hline $\begin{array}{l}\text { Bisht et al., } 2019 . \\
\text { Annals of } \\
\text { Neurosciences }\end{array}$ & 31975776 & 86 & $31.4 \pm 7.3$ & $\begin{array}{l}\text { Parents of } \\
\text { retinoblastoma } \\
\text { patients }\end{array}$ & $\begin{array}{l}\text { Yoga based } \\
\text { lifestyle } \\
\text { intervention for } \\
12 \text { weeks }\end{array}$ & $\begin{array}{l}\text { Stress was } \\
\text { reduced }\end{array}$ \\
\hline
\end{tabular}

The above list includes studies reported from 2019 till present.

developed and propagated the practice of simple yogic breathing practices including Isha kriya or long duration breathing technique, Simha kriya or short duration breathing technique, and Shambhavi Mahamudra Kriya (Table 2). A kriya is a yogic action or an inner technique, like controlling the breath. The most remarkable characteristic feature of these kriyas is that they are easy to learn and practice with simple instructions. They are free and app guided. Isha kriya is recommended to be done on empty stomach. Practicing Isha kriya calms mind and body, reduces stress, anxiety, and depression, energizes body, improves health and it is said to empower an individual in handling unpleasant situation around himself/herself. Recent interest is emerging on the efficacy and understanding the biological/physiological/psychological mechanisms of Isha Kriya. Although more research is required, the available literature points out that there is no side effect of Isha kriya (Narayanan et al., 2020); practicing it regularly, twice a day, is more fruitful for health. Interestingly, mood disturbances can be reduced in HCW by single-time Isha kriya practice shown in a pilot study examining the mood changes before and 
after practice in stressed HCW from surgical grand rounds and an anesthesia conference (Rangasamy et al., 2019). Isha followers often claim that individuals practicing Isha kriya are less susceptible to common cold and flu. However, it needs to be investigated.

Simha kriya, another kriya developed by Sadhguru, is said to boost the immune system, increase lung capacity, purifies body and the mind. It can even help identify individuals with respiratory problem as they are unable to perform Simha kriya after 4-5 days of regular practice. However, there are yet no direct studies reported in the literature.

Shambhavi Mahamudra Kriya is the most studied among the three kriyas, yet it has not been adequately investigated. It is a combination of Pranayama, yogic postures and meditation, again not prescribed in Yogic literature. A few studies have suggested that increase in the heart rate variability, sympathetic tone and vagal afferents balance is associated with Shambhavi Mahamudra Kriya (Selvaraj et al., 2008; Peterson et al., 2017). Though additional studies are warranted, one of the studies provides enough evidence of the relaxation with decreased stress and increased well-being (Sinha et al., 2013; Peterson et al., 2017). Due to COVID-19 pandemic interest in such techniques has reemerged especially with regard to the efficacy and understanding the biological/physiological mechanisms of Isha Kriya.
In contrast to above kriyas, Sudarshan kriya (SKY), evolved by Art of Living, is well studied and has shown to reduce stress and improve autonomic nervous system, immunity and wellbeing (Sharma et al., 2003; Brown and Gerbarg, 2005; Zope and Zope, 2013; Chandra et al., 2017; Mathersul et al., 2019). SKY can improve depression and can be beneficial for Posttraumatic stress disorder (Janakiramaiah et al., 2000; Katzman et al., 2012; Seppälä et al., 2014). SKY is beneficial in maintaining oxygen saturation in the practitioners at extreme high-altitude environment and thus reduces the risk of developing highaltitude related disorders (unpublished data). A recent study has shown reduction in stress, anxiety and depression among HCWs during COVID-19 pandemic after SKY intervention (Divya et al., 2021).

Such modifications based on yogic knowledge, require longitudinal randomized trials in comparison to established techniques for efficient integration (Nagendra et al., 2019; Nagarathna et al., 2019a). These breathing techniques are taught by different Yoga schools in India like Isha foundation, Art of Living and other such schools. The followers of these foundations constitute large numbers, either using these breathing techniques or obtaining training in the same. Therefore, it is easy to recruit a sufficient sample size and test such techniques as compared to the basic Yoga techniques. These kriyas often face barriers as there

TABLE 2 | Simple Yogic breathing practices.

\section{ISHA KRIYA OR LONGER DURATION BREATHING}

TECHNIQUE (LDBT) https://youtu.be/K4hCvdDn7Zc

Time interval: $\sim 12-18 \mathrm{~min}$

Preparation: Crossed leg posture with straight spine, hands on thighs with palms facing upward, face slightly upward, mild focus between the eyebrows

3 Stages

Stage 1

Inhale/Exhale, $7-11 \mathrm{~min}$

Utter "aa" 7 times, $\sim 1 \mathrm{~min}$

Sit silent for $\sim 5-6 \mathrm{~min}$
While inhaling mentally saying: I am not the body While exhaling mentally saying: I am not even the mind

Producing the sound from the navel region with mouth wide open. Not very loud but enough to feel the vibrations produced by the sound

Face slightly upward with mild focus between the eyebrows.

SIMHA KRIYA OR SHORT DURATION BREATHING

TECHNIQUE (SDBT) https://youtu.be/IP1Y1bk1YgU

Time Interval: $3-5 \mathrm{~min}$

Preparation: eyes closed, sit with cross legs

3 Stages

Stage 1

Powerful inhalation/exhalation

21 times with tongue outside,

Constrictions from the throat, No abdominal jerks

$\sim 1-2$ min

Stage 2

Tongue rolled inside by pushing

it back, 21 powerful

inhalation/exhalation, 1-2 min

Stage 3

Sit relaxed with fullness of

breath for $\sim 30 \mathrm{~s}-1 \mathrm{~min}$

Individuals aged $<6$ years, > 70 years or who have any kind of tumor or hemorrhage in brain should do Stage 1 and Stage 2 for 12 times only in SBDT. 
is an attempt for their application as a health care technique by general population (Mishra et al., 2020a,c).

Practicing Isha Kriya regularly, twice a day, is advocated to be fruitful for health. Isha foundation states that individuals practicing Isha kriya are less susceptible to common cold and flu. Hence, the combination of Isha kriya and Simha kriya are often apprised as important non-pharmacological strategy to manage COVID-19. Researchers recommend breathing techniques in COVID-19 management by boosting the immunological response, strengthening respiratory system and improving the immune response (Feng et al., 2020; Khawam et al., 2020). The combined practice might improve COVID19 by reducing stress, improving immunity, increasing lung capacity, reducing inflammation, and improving wellbeing. However, no proven stress reduction or immune enhancement by administrating yogic breathing such as Isha kriya has been shown. Unlike SKY, despite reported benefits from Isha kriya practitioners, comprehensive controlled trials haven't been undertaken.

We have earlier reported that pre-diabetics are more stressed than diabetic patients and a yoga intervention, i.e., Diabetes Yoga Protocol, which include breathing exercises, can slow down, if not halt, the conversion of pre-diabetic condition to diabetics by altering the stress responses (Mishra et al., 2020b). Thus, successful management of the co-morbidities may reduce the risk of COVID-19. The aforementioned simple kriyas are designed by Sadhguru to include effectiveness of modulated breathing in everyday routine and can thus reduce the risk of co-morbidities such as diabetes, hypertension and may be COVID-19. A doctor from United Kingdom suggested simple breathing technique, which is popular online, for getting relief from COVID-19 by encouraging gaseous exchange and oxygenation; this technique does not prevent or cure COVID-19 (Hamzelou, 2020).

As it is often argued among Yoga scholars that Isha kriya and Simha kriya may be useful for COVID-19 patients, a randomized pilot study is imperative to study the role of Isha kriya and Simha kriya with the biological/physiological therapeutic efficacy. In order to further evaluate the efficacy of Isha kriya and Simha kriya in COVID-19 a randomized case-control trial is in progress (Trial registration no. CTRI/2020/10/028195).

\section{PSYCHOLOGICAL STRESS AND IMMUNE RESPONSE}

The first report of immunosuppressive effect of psychological stress was approximately 50 years ago (Herbert and Cohen, 1993). A meta-analysis of 293 independent studies spanning 30 years has revealed that immunity is affected by acute and chronic stressors (Segerstrom and Miller, 2004). While acute stress suppresses some aspects of adaptive immunity and enhances some parameters of natural immunity, chronic stress suppresses cellular as well as humoral immunity. Brief but significant stressors, ranging from student examination to current COVID-19 pandemic, have potential to suppress the cellular immunity. Loneliness has also been shown to enhance stress and inflammation under acute stress conditions (Jaremka et al., 2013; Ozamiz-Etxebarria et al., 2020). Such observations may be seen in individuals who are quarantined, COVID-19 positive, convalescent or those suffering from loneliness (during lockdown), increasing their risk of suffering from severe COVID19 infection.

Asthma, the respiratory and common allergic disease of 21st century, is associated with psychological stress, anxiety and sadness and has a bidirectional association with panic (Lehrer et al., 2002; Hasler et al., 2005). Negative emotions such as anger and hostile behavior have negative effect on physiology including decline in lung function (Kubzansky et al., 2006). These can be avoided by Yogic interventions.

Studies have shown that psychological stress can increase risk of diabetes, upper respiratory infection and cancer, and has role in progression of cancer (Cohen et al., 2002; Afrisham et al., 2019). Presence of chronic diseases, especially respiratory disorder together with stress may enhance the degree of COVID-19, which may be further aggravated by presence of obesity. Respiratory function is decreased in obese due to decreased lung volume and accumulation of cytokine producing adipocytes (Mafort et al., 2016). It is to be noted that stress and obesity are interrelated because stress can lead to obesity (overeating response) or vice-versa (van der Valk et al., 2018). Nevertheless, both stress and obesity have adverse effect on respiratory function, which may increase the risk and severity of COVID-19. Yogic breathing is an important tool to improve oxygen saturation (Mason et al., 2013).

Furthermore, psychological stress is associated with enhanced susceptibility for viral infections (Perez et al., 2012). Natural killer cells tend to decrease under stress (Ma et al., 2013), which provides immunity until seroconversion and availability of IgG and IgM antibodies to neutralize SARS-CoV-2 in middle or later stages of COVID-19 (Xiang et al., 2020). Apparently, wound healing is also impaired under stress as indicated by increased expression of genes related to cell cycle arrest, apoptosis, and inflammation in wound site neutrophils (Roy et al., 2005).

Age is another risk factor of COVID-19 as immunity decreases with age (Nicholson, 2016). Hence, it is evident that presence of psychological stress in HCWs, quarantined individuals and COVID-19 positive cases may considerably hamper their ability to withstand COVID-19, both mentally and physically. Thus, Pranayama and other breathing techniques may play a substantial role in managing stress and improve immunity that might be beneficial in managing COVID-19 response, especially when patient is obese or aged and/or has chronic respiratory or other disorders. Moreover, use of mask is also an added challenge to a large number of people who are not able to breathe; thus, such yogic breathing can help.

We hypothesize that simple and controlled breathing techniques, such as Isha kriya or Simha kriya, may have role in managing COVID-19-related stress and immune response, which might be helpful in prevention or treatment as an additional and indirect approach. However, the direct involvement of Isha kriya or Simha kriya in psychological 
and physiological effects needs to be verified. Of note, standard precautionary measures and available drugs and vaccines are the major contributors in COVID-19 prevention and treatment.

\section{DISCUSSION}

Yoga may be instrumental in managing COVID-19 related stress and regulate immunity and inflammation. However, it is important to note that the key factors to control COVID-19 are prevention of the contagion, by following standard norms such as use of N-95 or regular masks, handwashing, use of sanitizers and social distancing. Moreover, vaccines are readily available and administered in almost all countries and trials are about to complete thereby the severity of this pandemic might reduce in coming time. However, emergence of new strains of SARS-CoV-2 is of concern, as the presently available vaccines might be unresponsive toward these strains. Yoga practices, which enhance immune system, apparently reduce inflammation and related stress (either associated with infection or loneliness during quarantine), and may aid in management of COVID-19 patients, convalescent cases and $\mathrm{HCWs}$, require validation through randomized clinical trial.

Immunity is adversely affected by increased stress. Psychological stress is often reported among the COVID-19 positive patients and those recovering from it, quarantined individuals and HCWs (Luo et al., 2020; Ornell et al., 2020; Pfefferbaum and North, 2020; Halperin et al., 2021). Therefore, it becomes crucial not only to improve immunity but also to reduce stress. Breathing techniques are known to improve the lung functions, oxygen saturation and improved cardiovascular functions. Liuzijue exercise that includes controlled breathing was able to improve pulmonary function and quality of life in discharged COVID19 patients (Tang et al., 2021). The best precautionary approach to cope up with COVID-19 is by enhancing immunity and lung functions. However, lack of specific Yoga modules or kriyas precludes extrapolation of controlled trials and their consequent translation. Several ongoing randomized control trials, including our study, aims to investigate the efficacy of various breathing techniques in COVID-19 (Lai et al., 2020; Weiner et al., 2020; Zhang et al., 2020). Figure 1 summarizes the effects of Yogic breathing techniques.

COVID19 outbreak and immediate requirement of precautionary measures and treatment has resulted in exploration of breathing techniques, including those outside the field of yogic texts. This may also act as a tool to manage COVID-19, especially in mild and moderate cases. However, drugs and vaccine are required to efficiently treat COVID19. Such breathing techniques are easy to access during the lockdown, including the HCWs, the quarantined and COVID19 positive patients, through digital platforms. The yoga scholars at Post Graduate Institute of Medical Education and

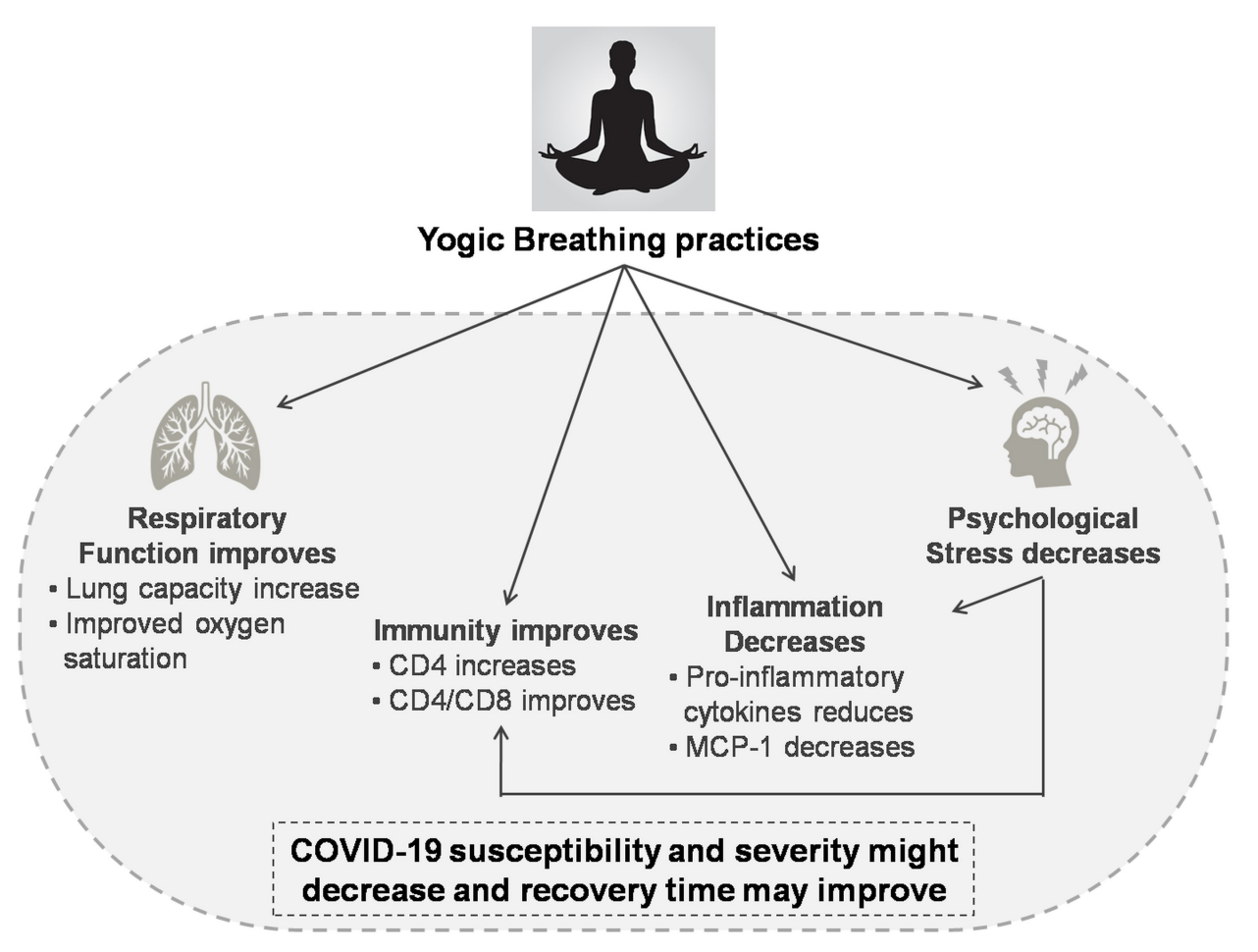

FIGURE 1 | Effects of Yogic breathing and probable advantage in COVID-19. Abbreviations: CD4, cluster of differentiation 4; CD8, cluster of differentiation 8; and MCP-1, Monocyte chemoattractant protein-1. 
Research, Chandigarh, India have spearheaded such a digital interface with educational programs that prompt scientific analysis of mindfulness programs via Facebook page, "Yoga Scholar PGIMER". The Isha kriya breathing technique was discussed by Sadhguru in one such program ${ }^{2}$.

Yogic breathing practice such as Isha kriya and Simha kriya are said to be simple to learn and do not require special training and supervision to execute. The combined practice only takes 15-20 min. Hence, Isha Kriya and Simha kriya must be evaluated for their efficacy through controlled trials.

${ }^{1}$ https://www.facebook.com/YogaScholarPGIMER/

${ }^{2}$ https://www.facebook.com/YogaScholarPGIMER/videos/235392504240583/

\section{REFERENCES}

Afrisham, R., Paknejad, M., Soliemanifar, O., Sadegh-Nejadi, S., Meshkani, R., and Ashtary-Larky, D. (2019). The influence of psychological stress on the initiation and progression of diabetes and cancer. Int. J. Endocrinol. Metab. 17:e67400.

Aggarwal, A., Baker, C., Evans, T., and Haslam, P. (2000). G-CSF and IL-8 but not GM-CSF correlate with severity of pulmonary neutrophilia in acute respiratory distress syndrome. Eur. Respir. J. 15, 895-901. doi: 10.1034/j.1399-3003.2000. 15e14.x

Alaparthi, G. K., Augustine, A. J., Anand, R., and Mahale, A. (2016). Comparison of diaphragmatic breathing exercise, volume and flow incentive spirometry, on diaphragm excursion and pulmonary function in patients undergoing laparoscopic surgery: a randomized controlled trial. Minim. Invasive Surg. 2016:1967532.

Andrés-Rodríguez, L., Borràs, X., Feliu-Soler, A., Pérez-Aranda, A., RozadillaSacanell, A., Montero-Marin, J., et al. (2019). Immune-inflammatory pathways and clinical changes in fibromyalgia patients treated with Mindfulness-Based Stress Reduction (MBSR): a randomized, controlled clinical trial. Brain. Behav. Immun. 80, 109-119. doi: 10.1016/j.bbi.2019.02.030

Antinori, S., Cossu, M. V., Ridolfo, A. L., Rech, R., Bonazzetti, C., Pagani, G., et al. (2020). Compassionate remdesivir treatment of severe Covid-19 pneumonia in intensive care unit (ICU) and Non-ICU patients: clinical outcome and differences in post_treatment hospitalisation status. Pharmacol. Res. 158:104899. doi: 10.1016/j.phrs.2020.104899

Asimakos, A., Toumpanakis, D., Karatza, M.-H., Vasileiou, S., Katsaounou, P., Mastora, Z., et al. (2018). Immune cell response to strenuous resistive breathing: comparison with whole body exercise and the effects of antioxidants. Int. J. Chron. Obstruct. Pulmon. Dis. 13:529. doi: 10.2147/copd.s154533

Bernardi, L., Wdowczyk-Szulc, J., Valenti, C., Castoldi, S., Passino, C., Spadacini, G., et al. (2000). Effects of controlled breathing, mental activity and mental stress with or without verbalization on heart rate variability. J. Am. Coll. Cardiol. 35, 1462-1469. doi: 10.1016/s0735-1097(00)00595-7

Bhavanani, A. B., Sanjay, Z., and Madanmohan. (2011). Immediate effect of sukha pranayama on cardiovascular variables in patients of hypertension. Int. J. Yoga Therap. 21, 73-76. doi: 10.17761/ijyt.21.1.y007g51341634172

Bisht, S., Chawla, B., Tolahunase, M., Mishra, R., and Dada, R. (2019). Impact of yoga based lifestyle intervention on psychological stress and quality of life in the parents of children with retinoblastoma. Ann. Neurosci. 26, 66-74. doi: 10.5214/ans.0972.7531.260206

Bower, J. E., and Irwin, M. R. (2016). Mind-body therapies and control of inflammatory biology: a descriptive review. Brain. Behav. Immun. 51, 1-11. doi: 10.1016/j.bbi.2015.06.012

Bressington, D., Mui, J., Yu, C., Leung, S. F., Cheung, K., Wu, C., et al. (2019). Feasibility of a group-based laughter yoga intervention as an adjunctive treatment for residual symptoms of depression, anxiety and stress in people with depression. J. Affect. Disord. 248, 42-51. doi: 10.1016/j.jad.2019.01.030

Brown, R. P., and Gerbarg, P. L. (2005). Sudarshan Kriya yogic breathing in the treatment of stress, anxiety, and depression: part I-neurophysiologic model. J. Altern. Complement. Med. 11, 189-201. doi: 10.1089/acm.2005.11.189

Budhi, R. B., Payghan, S., and Deepeshwar, S. (2019). Changes in lung function measures following Bhastrika Pranayama (bellows

\section{DATA AVAILABILITY STATEMENT}

Publicly available datasets were analyzed in this study. This data can be found here: https://www.neuroscienceresearchlab.org/.

\section{AUTHOR CONTRIBUTIONS}

MR wrote the first draft. BS, PA, and AA contributed to conception and design of the review. PM edited and critically reviewed the manuscript. All authors contributed to manuscript revision, read, and approved the submitted version.

breath) and running in healthy individuals. Int. J. Yoga 12:233. doi: 10.4103/ijoy.ijoy_43_18

Buijze, G., De Jong, H., Kox, M., van de Sande, M., Van Schaardenburg, D., Van Vugt, R., et al. (2019). An add-on training program involving breathing exercises, cold exposure, and meditation attenuates inflammation and disease activity in axial spondyloarthritis-A proof of concept trial. PLoS One 14:e0225749. doi: 10.1371/journal.pone.0225749

Carr, M. W., Roth, S. J., Luther, E., Rose, S. S., and Springer, T. A. (1994). Monocyte chemoattractant protein 1 acts as a T-lymphocyte chemoattractant. Proc. Natl. Acad. Sci. U.S.A. 91, 3652-3656. doi: 10.1073/pnas.91.9.3652

Cartwright, T., Cahill, M., and Sadana, V. (2020). A mixed methods evaluation of an individualised yoga therapy intervention for rheumatoid arthritis: pilot study. Complement. Ther. Med. 50:102339. doi: 10.1016/j.ctim.2020.102339

Casaburi, R., Porszasz, J., Burns, M. R., Carithers, E. R., Chang, R., and Cooper, C. B. (1997). Physiologic benefits of exercise training in rehabilitation of patients with severe chronic obstructive pulmonary disease. Am. J. Respir. Crit. Care Med. 155, 1541-1551. doi: 10.1164/ajrccm.155.5.9154855

Chan, J. F.-W., Kok, K.-H., Zhu, Z., Chu, H., To, K. K.-W., Yuan, S., et al. (2020). Genomic characterization of the 2019 novel human-pathogenic coronavirus isolated from a patient with atypical pneumonia after visiting Wuhan. Emerg. Microbes Infect. 9, 221-236. doi: 10.1080/22221751.2020.1719902

Chandra, B. H., Ramesh, M. N., and Nagendra, H. R. (2019). Effect of yoga on immune parameters, cognitive functions, and quality of life among HIVpositive children/adolescents: a pilot study. Int. J. Yoga 12:132. doi: 10.4103/ ijoy.ijoy_51_18

Chandra, S., Jaiswal, A. K., Singh, R., Jha, D., and Mittal, A. P. (2017). Mental stress: neurophysiology and its regulation by Sudarshan Kriya Yoga. Int. J. Yoga 10:67. doi: 10.4103/0973-6131.205508

Cohen, S. (2021). Psychosocial vulnerabilities to upper respiratory infectious illness: implications for susceptibility to coronavirus disease 2019 (COVID-19). Perspect. Psychol. Sci. 16, 161-174. doi: 10.1177/1745691620942516

Cohen, S., Hamrick, N., Rodriguez, M. S., Feldman, P. J., Rabin, B. S., and Manuck, S. B. (2002). Reactivity and vulnerability to stress-associated risk for upper respiratory illness. Psychosom. Med. 64, 302-310. doi: 10.1097/00006842200203000-00014

Cramer, H., Lauche, R., Klose, P., Lange, S., Langhorst, J., and Dobos, G. J. (2017). Yoga for improving health-related quality of life, mental health and cancerrelated symptoms in women diagnosed with breast cancer. Cochrane Database Syst. Rev. 1:CD010802.

Csepregi, É, Szekanecz, Z., and Szántó, S. (2019). The effects of breathing exercises in comparison with other exercise programs on cardiorespiratory fitness among healthy female college students. J. Sports Med. Phys. Fitness 60, 62-68.

Cucinotta, D., and Vanelli, M. (2020). WHO declares COVID-19 a pandemic. Acta Biomed. 91, 157-160.

Danhauer, S. C., Addington, E. L., Cohen, L., Sohl, S. J., Van Puymbroeck, M., Albinati, N. K., et al. (2019). Yoga for symptom management in oncology: a review of the evidence base and future directions for research. Cancer 125, 1979-1989. doi: 10.1002/cncr.31979

Dhimolea, E. (2010). Canakinumab. MAbs 2, 3-13. doi: 10.4161/mabs.2.1.10328 
Divya, K., Bharathi, S., Somya, R., and Darshan, M. H. (2021). Impact of a yogic breathing technique on the well-being of healthcare professionals during the COVID-19 pandemic. Glob. Adv. Health Med. 10:2164956120982956.

Duraimani, S., Schneider, R. H., Randall, O. S., Nidich, S. I., Xu, S., Ketete, M., et al. (2015). Effects of lifestyle modification on telomerase gene expression in hypertensive patients: a pilot trial of stress reduction and health education programs in African Americans. PLoS One 10:e0142689. doi: 10.1371/journal. pone. 0142689

Erdoğan Yüce, G., and Taşc1, S. (2020). Effect of pranayama breathing technique on asthma control, pulmonary function, and quality of life: a single-blind, randomized, controlled trial. Complement. Ther. Clin. Pract. 38:101081. doi: 10.1016/j.ctcp.2019.101081

Fang, S., Zheng, R., Lei, C., Zhou, R., Wang, J., and Li, M. (2021). In silico prediction of new mutations that can improve the binding abilities between 2019-nCoV coronavirus and human ACE2. IEEE/ACM Trans. Comput. Biol. Bioinform. doi: 10.1109/TCBB.2021.3058265 Online ahead of print

Feng, F., Tuchman, S., Denninger, J. W., Fricchione, G. L., and Yeung, A. (2020). Qigong for the Prevention, Treatment, and Rehabilitation of COVID19 Infection in Older Adults. Am. J. Geriatr. Psychiatry 28, 812-819. doi: 10.1016/j.jagp.2020.05.012

Gautam, S., Kumar, M., Kumar, U., and Dada, R. (2020). Effect of an 8week yoga-based lifestyle intervention on psycho-neuro-immune axis, disease activity, and perceived quality of life in rheumatoid arthritis patients: a randomized controlled trial. Front. Psychol. 11:2259. doi: $10.3389 /$ fpsyg.2020.02259

Gharaee-Kermani, M., Denholm, E. M., and Phan, S. H. (1996). Costimulation of fibroblast collagen and transforming growth factor $\beta 1$ gene expression by monocyte chemoattractant protein-1 via specific receptors. J. Biol. Chem. 271, 17779-17784. doi: 10.1074/jbc.271.30.17779

Glaser, R., Kiecolt-Glaser, J. K., Malarkey, W. B., and Sheridan, J. F. (1998). The influence of psychological stress on the immune response to vaccines. Ann. N. Y. Acad. Sci. 649-655. doi: 10.1111/j.1749-6632.1998.tb09603.x

Goldstein, M. R., Lewin, R. K., and Allen, J. (2020). Improvements in wellbeing and cardiac metrics of stress following a yogic breathing workshop: randomized controlled trial with active comparison. J. Am. Coll. Health doi: 10.1080/07448481.2020.1781867 Online ahead of print

Gonçalves, A. V., Makuch, M. Y., Setubal, M. S., Barros, N. F., and Bahamondes, L. (2016). A qualitative study on the practice of yoga for women with painassociated endometriosis. J. Altern. Complement. Med. 22, 977-982. doi: 10. 1089/acm.2016.0021

Grahn Kronhed, A. C., Enthoven, P., Spångeus, A., and Willerton, C. (2020). Mindfulness and modified medical yoga as intervention in older women with osteoporotic vertebral fracture. J. Altern. Complement. Med. 26, 610-619. doi: 10.1089/acm.2019.0450

Grein, J., Ohmagari, N., Shin, D., Diaz, G., Asperges, E., Castagna, A., et al. (2020). Compassionate use of remdesivir for patients with severe Covid-19. N. Engl. J. Med. 382, 2327-2336.

Gurung, P., and Kanneganti, T.-D. (2015). Novel roles for caspase-8 in IL-1 $\beta$ and inflammasome regulation. Am. J. Pathol. 185, 17-25. doi: 10.1016/j.ajpath.2014. 08.025

Hakked, C. S., Balakrishnan, R., and Krishnamurthy, M. N. (2017). Yogic breathing practices improve lung functions of competitive young swimmers. J. Ayurveda Integr. Med. 8, 99-104. doi: 10.1016/j.jaim.2016.12.005

Haller, H., Choi, K. E., Lange, S., Kümmel, S., Paul, A., Cramer, H., et al. (2020). Effects of an integrative mind-body-medicine group program for breast cancer patients during chemotherapy: an observational study. Curr. Pharm. Des. doi: $10.2174 / 1381612826666201211111122$ Online ahead of print.

Halperin, S. J., Henderson, M. N., Prenner, S., and Grauer, J. N. (2021). Prevalence of anxiety and depression among medical students during the Covid-19 pandemic: a cross-sectional study. J. Med. Educ. Curric. Dev. 8:2382120521991150.

Hamzelou, J. (2020). Can breathing exercises help protect you from covid-19? New Sci. 246, 10-11. doi: 10.1016/s0262-4079(20)30789-2

Hasler, G., Gergen, P. J., Kleinbaum, D. G., Ajdacic, V., Gamma, A., Eich, D., et al. (2005). Asthma and panic in young adults: a 20-year prospective community study. Am. J. Respir. Crit. Care Med. 171, 1224-1230. doi: 10.1164/rccm. 200412-1669oc
Herbert, T. B., and Cohen, S. (1993). Stress and immunity in humans: a meta-analysis review. Psychosom. Med. 55, 364-364. doi: 10.1097/00006842199307000-00004

Hilcove, K., Marceau, C., Thekdi, P., Larkey, L., Brewer, M. A., and Jones, K. (2020). Holistic nursing in practice: mindfulness-based yoga as an intervention to manage stress and burnout. J. Holist. Nurs. doi: 10.1177/0898010120921587 Online ahead of print

Hogaboam, C. M., Bone-Larson, C. L., Lipinski, S., Lukacs, N. W., Chensue, S. W., Strieter, R. M., et al. (1999). Differential monocyte chemoattractant protein-1 and chemokine receptor 2 expression by murine lung fibroblasts derived from Th1-and Th2-type pulmonary granuloma models. J. Immunol. 163, 2193-2201.

Hou, Y. J., Okuda, K., Edwards, C. E., Martinez, D. R., Asakura, T., Dinnon, K. H., et al. (2020). SARS-CoV-2 reverse genetics reveals a variable infection gradient in the respiratory tract. Cell 182, 429.e14-446.e14.

Hung, I. F.-N., Lung, K.-C., Tso, E. Y.-K., Liu, R., Chung, T. W.-H., Chu, M.-Y., et al. (2020). Triple combination of interferon beta-1b, lopinavir-ritonavir, and ribavirin in the treatment of patients admitted to hospital with COVID-19: an open-label, randomised, phase 2 trial. Lancet 395, 1695-1704.

Janakiramaiah, N., Gangadhar, B. N., Naga Venkatesha Murthy, P. J., Harish, M. G., Subbakrishna, D. K., and Vedamurthachar, A. (2000). Antidepressant efficacy of Sudarshan Kriya Yoga (SKY) in melancholia: a randomized comparison with electroconvulsive therapy (ECT) and imipramine. J. Affect. Disord. 57, 255-259. doi: 10.1016/s0165-0327(99)00079-8

Jaremka, L. M., Fagundes, C. P., Peng, J., Bennett, J. M., Glaser, R., Malarkey, W. B., et al. (2013). Loneliness promotes inflammation during acute stress. Psychol. Sci. 24, 1089-1097. doi: 10.1177/0956797612464059

Joo, S., Shin, D., and Song, C. (2015). The effects of game-based breathing exercise on pulmonary function in stroke patients: a preliminary Study. Med. Sci. Monit. 21, 1806-1811. doi: 10.12659/msm.893420

Joseph, B., Nair, P. M., and Nanda, A. (2015). Effects of naturopathy and yoga intervention on CD4 count of the individuals receiving antiretroviral therapyreport from a human immunodeficiency virus sanatorium. Pune. Int. J. Yoga 8, 122-127. doi: 10.4103/0973-6131.158475

Kalil, A. C., Patterson, T. F., Mehta, A. K., Tomashek, K. M., Wolfe, C. R., Ghazaryan, V., et al. (2020). Baricitinib plus remdesivir for hospitalized adults with Covid-19. N. Engl. J. Med. 384, 795-807.

Kaliman, P., Álvarez-López, M. J., Cosín-Tomás, M., Rosenkranz, M. A., Lutz, A., and Davidson, R. J. (2014). Rapid changes in histone deacetylases and inflammatory gene expression in expert meditators. Psychoneuroendocrinology 40, 96-107. doi: 10.1016/j.psyneuen.2013.11.004

Kaminsky, D. A., Guntupalli, K. K., Lippmann, J., Burns, S. M., Brock, M. A., Skelly, J., et al. (2017). Effect of yoga breathing (pranayama) on exercise tolerance in patients with chronic obstructive pulmonary disease: a randomized, controlled trial. J. Altern. Complement. Med. 23, 696-704. doi: 10.1089/acm.2017.0102

Katzman, M. A., Vermani, M., Gerbarg, P. L., Brown, R. P., Iorio, C., Davis, M., et al. (2012). A multicomponent yoga-based, breath intervention program as an adjunctive treatment in patients suffering from generalized anxiety disorder with or without comorbidities. Int. J. Yoga 5, 57-65. doi: 10.4103/0973-6131. 91716

Khawam, E., Khouli, H., and Pozuelo, L. (2020). Treating acute anxiety in patients with COVID-19. Cleve. Clin. J. Med. doi: 10.3949/ccjm.87a.ccc016 Online ahead of print

Kiecolt-Glaser, J. K., Christian, L., Preston, H., Houts, C. R., Malarkey, W. B., Emery, C. F., et al. (2010). Stress, inflammation, and yoga practice. Psychosom. Med. 72, 113-121. doi: 10.1097/psy.0b013e3181cb9377

Kubzansky, L. D., Sparrow, D., Jackson, B., Cohen, S., Weiss, S. T., and Wright, R. J. (2006). Angry breathing: a prospective study of hostility and lung function in the Normative Aging Study. Thorax 61, 863-868. doi: 10.1136/thx.2005.050971

Kuo, J. R., Zeifman, R. J., Morrison, A. S., Heimberg, R. G., Goldin, P. R., and Gross, J. J. (2021). The moderating effects of anger suppression and anger expression on cognitive behavioral group therapy and mindfulness-based stress reduction among individuals with social anxiety disorder. J. Affect. Disord. 285, 127-135. doi: 10.1016/j.jad.2021.02.022

Kuppusamy, M., Kamaldeen, D., Pitani, R., Amaldas, J., and Shanmugam, P. (2018). Effects of Bhramari Pranayama on health-a systematic review. J. Tradit. Complement. Med. 8, 11-16. doi: 10.1016/j.jtcme.2017.02.003 
Kwok, J., Kwan, J., Auyeung, M., Mok, V., Lau, C., Choi, K. C., et al. (2019). Effects of mindfulness yoga vs stretching and resistance training exercises on anxiety and depression for people with parkinson disease: a randomized clinical trial. JAMA Neurol. 76, 755-763. doi: 10.1001/jamaneurol.2019.0534

La Torre, G., Raffone, A., Peruzzo, M., Calabrese, L., Cocchiara, R. A., D’Egidio, V., et al. (2020). Yoga and mindfulness as a tool for influencing affectivity, anxiety, mental health, and stress among healthcare workers: results of a single-arm clinical trial. J. Clin. Med. 9:1037. doi: 10.3390/jcm9041037

Lai, K. S. P., Watt, C., Ionson, E., Baruss, I., Forchuk, C., Sukhera, J., et al. (2020). Breath Regulation and yogic Exercise An online Therapy for calm and Happiness (BREATH) for frontline hospital and long-term care home staff managing the COVID-19 pandemic: a structured summary of a study protocol for a feasibility study for a randomised controlled trial. Trials 21:648.

Lehrer, P., Feldman, J., Giardino, N., Song, H.-S., and Schmaling, K. (2002). Psychological aspects of asthma. J. Consult. Clin. Psychol. 70, 691-711.

Leung, K., Shum, M. H., Leung, G. M., Lam, T. T., and Wu, J. T. (2021). Early transmissibility assessment of the N501Y mutant strains of SARS-CoV-2 in the United Kingdom, October to November 2020. Euro. Surveill. 26:2002106.

Levi, M., Schultz, M. J., Rijneveld, A. W., and van der Poll, T. (2003). Bronchoalveolar coagulation and fibrinolysis in endotoxemia and pneumonia. Crit. Care Med. 31, S238-S242.

Lundien, M. C., Mohammed, K. A., Nasreen, N., Tepper, R., Hardwick, J. A., Sanders, K. L., et al. (2002). Induction of MCP-1 expression in airway epithelial cells: role of CCR2 receptor in airway epithelial injury. J. Clin. Immunol. 22, 144-152.

Luo, M., Guo, L., Yu, M., Jiang, W., and Wang, H. (2020). The psychological and mental impact of coronavirus disease 2019 (COVID-19) on medical staff and general public - a systematic review and meta-analysis. Psychiatry Res. 291:113190. doi: 10.1016/j.psychres.2020.113190

Ma, Z., Liu, Y., Zhou, X., Yu, H.-L., Li, M.-Q., Tomiyama-Miyaji, C., et al. (2013). Research on stress-induced apoptosis of natural killer cells and the alteration of their killing activity in mouse liver. World J. Gastroenterol. 19, 6258-6264. doi: 10.3748/wjg.v19.i37.6258

Madison, A. A., Shrout, M. R., Renna, M. E., and Kiecolt-Glaser, J. K. (2021). Psychological and behavioral predictors of vaccine efficacy: considerations for COVID-19. Perspect. Psychol. Sci. 16, 191-203. doi: 10.1177/1745691621989243

Mafort, T. T., Rufino, R., Costa, C. H., and Lopes, A. J. (2016). Obesity: systemic and pulmonary complications, biochemical abnormalities, and impairment of lung function. Multidiscip. Respir. Med. 11:28.

Marshall, M., McClanahan, M., McArthur Warren, S., Rogers, R., and Ballmann, C. (2020). A comparison of the acute effects of different forms of yoga on physiological and psychological stress: a pilot study. Int. J. Environ. Res. Public Health 17:6090. doi: 10.3390/ijerph17176090

Martarelli, D., Cocchioni, M., Scuri, S., and Pompei, P. (2011). Diaphragmatic breathing reduces exercise-induced oxidative stress. Evid. Based Complement. Alternat. Med. 2011:932430.

Mason, H., Vandoni, M., Debarbieri, G., Codrons, E., Ugargol, V., and Bernardi, L. (2013). Cardiovascular and respiratory effect of yogic slow breathing in the yoga beginner: what is the best approach? Evid. Based Complement. Alternat. Med. 2013:743504.

Mathersul, D. C., Tang, J. S., Schulz-Heik, R. J., Avery, T. J., Seppälä, E. M., and Bayley, P. J. (2019). Study protocol for a non-inferiority randomised controlled trial of SKY breathing meditation versus cognitive processing therapy for PTSD among veterans. BMJ Open 9:e027150. doi: 10.1136/bmjopen-2018-027150

McDonnell, K. K., Gallerani, D. G., Newsome, B. R., Owens, O. L., Beer, J., MyrenBennett, A. R., et al. (2020). A Prospective pilot study evaluating feasibility and preliminary effects of breathe easier: a mindfulness-based intervention for survivors of lung cancer and their family members (Dyads). Integr. Cancer Ther. 19:1534735420969829.

McGarvey, L., Dunbar, K., Martin, S., Brown, V., Macmahon, J., Ennis, M., et al. (2002). Cytokine concentrations and neutrophil elastase activity in bronchoalveolar lavage and induced sputum from patients with cystic fibrosis, mild asthma and healthy volunteers. J. Cyst. Fibros. 1, 269-275. doi: 10.1016/ s1569-1993(02)00098-x

Mishra, A., Chawathey, S. A., Mehra, P., Nagarathna, R., Anand, A., Rajesh, S., et al. (2020a). Perceptions of benefits and barriers to Yoga practice across rural and urban India: implications for workplace Yoga. Work 65, 721-732. doi: 10.3233/wor-203126

Mishra, A., Podder, V., Modgil, S., Khosla, R., Anand, A., Nagarathna, R., et al. (2020b). Perceived stress and depression in prediabetes and diabetes in an Indian population-A call for a mindfulness-based intervention. Gen. Hosp. Psychiatry 64, 127-128. doi: 10.1016/j.genhosppsych.2020.01.001

Mishra, A. S., Sk, R., Hs, V., Nagarathna, R., Anand, A., Bhutani, H., et al. (2020c). Knowledge, attitude, and practice of yoga in rural and Urban India, KAPY 2017: a nationwide cluster sample survey. Medicines 7:8. doi: 10.3390/ medicines7020008

Miyoshi, Y. (2019). Restorative yoga for occupational stress among Japanese female nurses working night shift: randomized crossover trial. J. Occup. Health 61, 508-516. doi: 10.1002/1348-9585.12080

Moore, H. B., Barrett, C. D., Moore, E. E., McIntyre, R. C., Moore, P. K., Talmor, D. S., et al. (2020). Is there a role for tissue plasminogen activator as a novel treatment for refractory COVID-19 associated acute respiratory distress syndrome? Trauma Acute Care Surg. 88, 713-714. doi: 10.1097/ta. 0000000000002694

Muktibodhananda, S. (2012). Hatha Yoga Pradipika. Munger: Sri Satguru Publications.

Nagarathna, R., Rajesh, S., Amit, S., Patil, S., Anand, A., and Nagendra, H. (2019a). Methodology of Niyantrita Madhumeha Bharata Abhiyaan-2017, a nationwide multicentric trial on the effect of a validated culturally acceptable lifestyle intervention for primary prevention of diabetes: part 2. Int. J. Yoga 12, 193-205. doi: 10.4103/ijoy.ijoy_38_19

Nagarathna, R., Tyagi, R., Kaur, G., Vendan, V., Acharya, I. N., Anand, A., et al. (2019b). Efficacy of a validated yoga protocol on dyslipidemia in diabetes patients: NMB-2017 India trial. Medicines 6:100. doi: 10.3390/ medicines 6040100

Nagendra, H., Nagarathna, R., Rajesh, S., Amit, S., Telles, S., and Hankey, A. (2019). Niyantrita Madhumeha Bharata 2017, methodology for a nationwide diabetes prevalence estimate: part 1. Int. J. Yoga 12, 179-192. doi: 10.4103/ijoy.ijoy_ 40_18

Narayanan, S., Reddy, A., Lopez, G., Liu, W., Wu, J., Liu, D., et al. (2020). Randomized feasibility study of meditative practices in hospitalized cancer patients. Integr. Cancer Ther. 19:1534735420909903.

Nicholson, L. B. (2016). The immune system. Essays Biochem. 60, 275-301.

Nirwan, M., Halder, K., Saha, M., Pathak, A., Balakrishnan, R., and Ganju, L. (2020). Improvement in resilience and stress-related blood markers following ten months yoga practice in Antarctica. J. Complement. Integr. Med. 18, 201207. doi: 10.1515/jcim-2019-0240

Ofei-Dodoo, S., Cleland-Leighton, A., Nilsen, K., Cloward, J. L., and Casey, E. (2020). Impact of a mindfulness-based, workplace group yoga intervention on burnout, self-care, and compassion in health care professionals: a pilot study. J. Occup. Environ. Med. 62, 581-587. doi: 10.1097/jom.0000000000001892

Okour, M., Al-Kofahi, M., and Austin, D. (2020). Hydroxychloroquine and azithromycin as potential treatments for COVID-19; clinical status impacts the outcome. J. Pharmacokinet. Pharmacodyn. 47, 187-188. doi: 10.1007/s10928020-09689-x

Ornell, F., Halpern, S. C., Kessler, F. H. P., and Narvaez, J. C. D. M. (2020) The impact of the COVID-19 pandemic on the mental health of healthcare professionals. Cad. Saude Publica 36:e0063520.

Orosa-Duarte, Á, Mediavilla, R., Muñoz-Sanjose, A., Palao, Á, Garde, J., LópezHerrero, V., et al. (2021). Mindfulness-based mobile app reduces anxiety and increases self-compassion in healthcare students: a randomised controlled trial. Med. Teach. doi: 10.1080/0142159X.2021.1887835 Online ahead of print

Ozamiz-Etxebarria, N., Dosil-Santamaria, M., Picaza-Gorrochategui, M., and Idoiaga-Mondragon, N. (2020). Stress, anxiety, and depression levels in the initial stage of the COVID-19 outbreak in a population sample in the northern Spain. Cad. Saude Publica 36:e00054020.

Ozono, S., Zhang, Y., Ode, H., Sano, K., Tan, T. S., Imai, K., et al. (2021). SARS-CoV-2 D614G spike mutation increases entry efficiency with enhanced ACE2-binding affinity. Nat. Commun. 12:848.

Pattnaik, S. J., Prasad, R. K., Jyotirmay, Pani, P., Nishant, and Kumar, S. (2020). Yoga as a holistic approach for stress management in oral cancer patients. A prospective study. J. Family Med. Prim. Care 9, 4200-4204. doi: 10.4103/ jfmpc.jfmpc_612_20 
Pedersen, A. F., Zachariae, R., and Bovbjerg, D. H. (2009). Psychological stress and antibody response to influenza vaccination: a meta-analysis. Brain. Behav. Immun. 23, 427-433. doi: 10.1016/j.bbi.2009.01.004

Perez, V., Uddin, M., Galea, S., Monto, A. S., and Aiello, A. E. (2012). Stress, adherence to preventive measures for reducing influenza transmission and influenza-like illness. J. Epidemiol. Community Health 66, 605-610. doi: 10. 1136/jech.2010.117002

Peterson, C. T., Bauer, S. M., Chopra, D., Mills, P. J., and Maturi, R. K. (2017). Effects of shambhavi mahamudra kriya, a multicomponent breath-based yogic practice (Pranayama), on perceived stress and general well-being. J. Evid. Based Complement. Altern. Med. 22, 788-797. doi: 10.1177/2156587217730934

Pfefferbaum, B., and North, C. S. (2020). Mental health and the Covid-19 pandemic. N. Engl. J. Med. 383, 510-512.

Pramanik, T., Sharma, H. O., Mishra, S., Mishra, A., Prajapati, R., and Singh, S. (2009). Immediate effect of slow pace bhastrika pranayama on blood pressure and heart rate. J. Altern. Complement. Med. 15, 293-295.

Rangasamy, V., Thampi Susheela, A., Mueller, A., F H Chang, T., Sadhasivam, S., and Subramaniam, B. (2019). The effect of a one-time 15-minute guided meditation (Isha Kriya) on stress and mood disturbances among operating room professionals: a prospective interventional pilot study. F1000Res. 8:335. doi: 10.12688/f1000research.18446.1

Reich, R. R., Lengacher, C. A., Klein, T. W., Newton, C., Shivers, S., Ramesar, S., et al. (2017). A randomized controlled trial of the effects of mindfulness-based stress reduction (MBSR[BC]) on levels of inflammatory biomarkers among recovering breast cancer survivors. Biol. Res. Nurs. 19, 456-464. doi: 10.1177/ 1099800417707268

Roy, S., Khanna, S., Yeh, P.-E., Rink, C., Malarkey, W. B., Kiecolt-Glaser, J., et al. (2005). Wound site neutrophil transcriptome in response to psychological stress in young men. Gene Expr. 12, 273-287. doi: 10.3727/000000005783992025

Sadhasivam, S., Alankar, S., Maturi, R., Vishnubhotla, R. V., Mudigonda, M., Pawale, D., et al. (2020). Inner engineering practices and advanced 4-day isha yoga retreat are associated with cannabimimetic effects with increased endocannabinoids and short-term and sustained improvement in mental health: a prospective observational study of meditators. Evid. Based Complement. Alternat. Med. 2020:8438272.

Sahni, P. S., Singh, K., Sharma, N., and Garg, R. (2021). Yoga an effective strategy for self-management of stress-related problems and wellbeing during COVID19 lockdown: a cross-sectional study. PLoS One 16:e0245214. doi: 10.1371/journal. pone. 0245214

Schanche, E., Vøllestad, J., Visted, E., Svendsen, J. L., Osnes, B., Binder, P. E., et al. (2020). The effects of mindfulness-based cognitive therapy on risk and protective factors of depressive relapse - a randomized wait-list controlled trial. BMC Psychol. 8:57. doi: 10.1186/s40359-020-00417-1

Segerstrom, S. C., and Miller, G. E. (2004). Psychological stress and the human immune system: a meta-analytic study of 30 years of inquiry. Psychol. Bull. 130:601. doi: 10.1037/0033-2909.130.4.601

Selvaraj, N., Shivplara, N. B., Bhatia, M., Santhosh, J., Deepak, K. K., and Anand, S. (2008). Heart rate dynamics during shambhavi mahamudra-a practice of Isha Yoga. J. Complement. Integr. Med. 5, 1553-3840.

Seppälä, E. M., Nitschke, J. B., Tudorascu, D. L., Hayes, A., Goldstein, M. R., Nguyen, D. T., et al. (2014). Breathing-based meditation decreases posttraumatic stress disorder symptoms in U.S. military veterans: a randomized controlled longitudinal study. J. Trauma. Stress 27, 397-405. doi: 10.1002/jts. 21936

Sharma, H., Sen, S., Singh, A., Bhardwaj, N. K., Kochupillai, V., and Singh, N. (2003). Sudarshan Kriya practitioners exhibit better antioxidant status and lower blood lactate levels. Biol. Psychol. 63, 281-291. doi: 10.1016/s03010511(03)00071-1

Sharma, K., Pailoor, S., Choudhary, N. R., Bhat, P., and Shrestha, S. (2020). Integrated yoga practice in cardiac rehabilitation program: a randomized control trial. J. Altern. Complement. Med. 26, 918-927. doi: 10.1089/acm.2019. 0250

Sharma, V. K., Rajajeyakumar, M., Velkumary, S., Subramanian, S. K., Bhavanani, A. B., Madanmohan, A. S., et al. (2014). Effect of fast and slow pranayama practice on cognitive functions in healthy volunteers. J. Clin. Diagn. Res. 8, $10-13$.

Shetty, P. (2017). Effects of sheetali and sheetkari pranayamas on blood pressure and autonomic function in hypertensive patients. Integr. Med. 16, 32-37.
Sinha, A. N., DeePAK, D., and Gusain, V. S. (2013). Assessment of the effects of pranayama/alternate nostril breathing on the parasympathetic nervous system in young adults. J. Clin. Diagn. Res. 7, 821-823.

Strauss, C., Gu, J., Montero-Marin, J., Whittington, A., Chapman, C., and Kuyken, W. (2021). Reducing stress and promoting well-being in healthcare workers using mindfulness-based cognitive therapy for life. Int. J. Clin. Health Psychol. 21:100227. doi: 10.1016/j.ijchp.2021.100227

Sungnak, W., Huang, N., Bécavin, C., Berg, M., Queen, R., Litvinukova, M., et al. (2020). SARS-CoV-2 entry factors are highly expressed in nasal epithelial cells together with innate immune genes. Nat. Med. 26, 681-687. doi: 10.1038/ s41591-020-0868-6

Tang, Y., Jiang, J., Shen, P., Li, M., You, H., Liu, C., et al. (2021). Liuzijue is a promising exercise option for rehabilitating discharged COVID-19 patients. Medicine 100:e24564. doi: 10.1097/md.0000000000024564

Tang, Y.-Y., Fan, Y., Lu, Q., Tan, L.-H., Tang, R., Kaplan, R. M., et al. (2020). Longterm physical exercise and mindfulness practice in an aging population. Front. Psychol. 11:358. doi: 10.3389/fpsyg.2020.00358

Thanalakshmi, J., Ravindran, R., Sembulingam, K., and Sembulingam, P. (2014). Impact of sheetali and sheetkari pranayama on the topographic mapping of the brain waves. IOSR J. Pharm. 4, 51-57. doi: 10.9790/3013-04010051057

Thirthalli, J., Naveen, G., Rao, M., Varambally, S., Christopher, R., and Gangadhar, B. (2013). Cortisol and antidepressant effects of yoga. Indian J. Psychiatry 55(Suppl. 3), S405-S408.

Tian, S., Hu, W., Niu, L., Liu, H., Xu, H., and Xiao, S.-Y. (2020). Pulmonary pathology of early phase 2019 novel coronavirus (COVID-19) pneumonia in two patients with lung cancer. J. Thorac. Oncol. 15, 700-704. doi: 10.1016/j. jtho.2020.02.010

Tong, J., Qi, X., He, Z., Chen, S., Pedersen, S. J., Cooley, P. D., et al. (2020). The immediate and durable effects of yoga and physical fitness exercises on stress. J. Am. Coll. Health doi: 10.1080/07448481.2019.1705840 Online ahead of print

Twal, W. O., Wahlquist, A. E., and Balasubramanian, S. (2016). Yogic breathing when compared to attention control reduces the levels of pro-inflammatory biomarkers in saliva: a pilot randomized controlled trial. BMC Complement. Altern. Med. 16:294. doi: 10.1186/s12906-016-1286-7

Valenza, M. C., Valenza-Peña, G., Torres-Sánchez, I., González-Jiménez, E., CondeValero, A., and Valenza-Demet, G. (2014). Effectiveness of controlled breathing techniques on anxiety and depression in hospitalized patients with COPD: a randomized clinical trial. Respir. Care 59, 209-215. doi: 10.4187/respcare. 02565

Valk, S. J., Piechotta, V., Chai, K. L., Doree, C., Monsef, I., Wood, E. M., et al. (2020). Convalescent plasma or hyperimmune immunoglobulin for people with COVID-19: a rapid review. Cochrane Database Syst. Rev. 5:CD013600.

van der Valk, E. S., Savas, M., and van Rossum, E. F. (2018). Stress and obesity: are there more susceptible individuals? Curr. Obes. Rep. 7, 193-203. doi: 10.1007/ s13679-018-0306-y

Venkatesh, H., Ravish, H., Silvia, C. W. D., and Srinivas, H. (2020). Molecular signature of the immune response to yoga therapy in stressrelated chronic disease conditions: an insight. Int. J. Yoga 13, 9-17. doi: 10.4103/ijoy.ijoy_82_18

Verma, A., Shete, S. U., and Doddoli, G. (2020). Impact of residential yoga training on occupational stress and health promotion in principals. J. Educ. Health Promot. 9:30.

Vieira, D. S., Mendes, L. P., Elmiro, N. S., Velloso, M., Britto, R. R., and Parreira, V. F. (2014). Breathing exercises: influence on breathing patterns and thoracoabdominal motion in healthy subjects. Braz. J. Phys. Ther. 18, 544-552. doi: 10.1590/bjpt-rbf.2014.0048

Wang, D., Hu, B., Hu, C., Zhu, F., Liu, X., Zhang, J., et al. (2020). Clinical characteristics of 138 hospitalized patients with 2019 novel coronavirusinfected pneumonia in Wuhan China. JAMA 323, 1061-1069. doi: 10.1001/ jama.2020.1585

Weiner, L., Berna, F., Nourry, N., Severac, F., Vidailhet, P., and Mengin, A. C. (2020). Efficacy of an online cognitive behavioral therapy program developed for healthcare workers during the COVID-19 pandemic: the REduction of STress (REST) study protocol for a randomized controlled trial. Trials 21:870.

Welty-Wolf, K. E., Carraway, M. S., Ortel, T. L., and Piantadosi, C. A. (2002). Coagulation and inflammation in acute lung injury. Thromb. Haemost. $88,17-25$.

WHO (2020a). Coronavirus disease (COVID-19): Vaccines. Available: https://www.who.int/news-room/q-a-detail/coronavirus-disease-(covid-19)- 
vaccines?adgroupsurvey=adgroupsurvey\&gclid=EAIaIQobChMIrK6bo8eT7 $\mathrm{w}$ IVUSlyCh2w3QWXEAAYASAAEgKGfPD_BwE (accessed March 3, 2021)

WHO (2020b). WHO Coronavirus Disease (COVID-19) Dashboard. Available: $\quad$ https://covid19.who.int/?gclid=EAIaIQobChMItN Rm7DC6gIVVH8rCh3hTQ7eEAAYASAAEgKm1_D_BwE (accessed September 4, 2020).

Wölfel, R., Corman, V. M., Guggemos, W., Seilmaier, M., Zange, S., Müller, M. A., et al. (2020). Virological assessment of hospitalized patients with COVID-2019. Nature 581, 465-469. doi: 10.1038/s41586-0202196-x

Xiang, F., Wang, X., He, X., Peng, Z., Yang, B., Zhang, J., et al. (2020). Antibody detection and dynamic characteristics in patients with COVID-19. Clin. Infect. Dis. 71, 1930-1934.

Zeng, Z., Xu, L., Xie, X. Y., Yan, H. L., Xie, B. J., Xu, W. Z., et al. (2020). Pulmonary pathology of early phase COVID-19 pneumonia in a patient with a benign lung lesion. Histopathology 77, 823-831. doi: 10.1111/his.14138

Zhang, S., Zhu, Q., Zhan, C., Cheng, W., Mingfang, X., Fang, M., et al. (2020). Acupressure therapy and Liu Zi Jue Qigong for pulmonary function and quality of life in patients with severe novel coronavirus pneumonia (COVID-19): a study protocol for a randomized controlled trial. Trials 21: 751.
Zhao, C.-Z., Fang, X.-C., Wang, D., and Wang, X.-D. (2010). Involvement of type II pneumocytes in the pathogenesis of chronic obstructive pulmonary disease. Respir. Med. 104, 1391-1395. doi: 10.1016/j.rmed.2010.06.018

Ziegler, C., Allon, S. J., Nyquist, S. K., Mbano, I. M., Miao, V. N., Tzouanas, C. N., et al. (2020). SARS-CoV-2 receptor ACE2 is an interferon-stimulated gene in human airway epithelial cells and is detected in specific cell subsets across tissues. Cell 181, 1016.e19-1035.e19.

Zope, S. A., and Zope, R. A. (2013). Sudarshan kriya yoga: breathing for health. Int. J. Yoga 6, 4-10. doi: 10.4103/0973-6131.105935

Conflict of Interest: The authors declare that the research was conducted in the absence of any commercial or financial relationships that could be construed as a potential conflict of interest.

Copyright (c) 2021 Rain, Subramaniam, Avti, Mahajan and Anand. This is an openaccess article distributed under the terms of the Creative Commons Attribution License (CC BY). The use, distribution or reproduction in other forums is permitted, provided the original author(s) and the copyright owner(s) are credited and that the original publication in this journal is cited, in accordance with accepted academic practice. No use, distribution or reproduction is permitted which does not comply with these terms. 